\title{
IMPLEMENTING GUIDED QUESTION TECHNIQUE TO INCREASE STUDENTS' WRITING SKILL
}

\author{
Syaifudin Latif Darmawan ${ }^{\mathbf{1}}$, \\ *Universitas Muhammadiyah Metro, Jl. Ki Hajar Dewantara No. 116 Iringmulyo Kota \\ Metro,Email: latifdar2011@gmail.com \\ Ani Andrianti ${ }^{2}$, \\ **Universitas Muhammadiyah Metro, Jl. Ki Hajar Dewantara No. 116 Iringmulyo Kota \\ Metro,Email: Aniandrianti60@gmail.com
}

\begin{abstract}
:
This study is classrom action research. It is carried out at SMP N 2 Metro in Academic Year of 2017/2018. The objectives of the research: (1) to find out whether guided question technique can increase the students' writing skill in descriptive text; (2) to describe the process of teaching writing using guided question technique. The population of the research is the seventh grade students of SMP N 2 Metro in academic year 2017/2018 that consist of 32 students.

The research is conducted in two cycles. The procedure of the research consists of identifying the problem, planning the action, implementing the action, observing the action, and reflecting the result of the research. Qualitative data are collected through interview, observation. In the meantime, quantitative data are collected through test. To analyze qualitative data, the researchers use miles and huberman model. It consists of three steps: data reduction, data display and data conclusion. Meanwhile, to analyze quantitative data, the researchers employ descriptive statistic.

The result of the research indicates that the implementation of guided question technique improved the students' writing skill in descriptive text. The average score of pretest is 56. In the cycle 1, the researchers giving the treatment and get the students' average score of post-test 1 is 69,23 . After applying the revised planning in cycle 2 , the average students' score in post-test 2 is 76 . It has reached $75 \%$ of 32 students that indicated the students passed the criterion of success. The result of students' participation in cycle 1 and cycle 2 did a significant progress and improves in every meeting of each cycle. In addition, the use of guided questions technique is able to increase the students' writing skill in descriptive text. The research has some suggestions; for the English teacher, it is useful to implement guided questions technique as one alternatives teaching, for the students it can be used to make the students easier in writing a text and for the further researcher this study can be used as a reference.
\end{abstract}

Key Words: Guided Question, Writing Skill

\section{Introduction}

Writing as one of language skills plays an important role in the formal communication. Writing is regarded as a productive skill. Writing being the most difficult skill for not only it needs a lot of vocabularies for composing paragraph, but also the writer should have a good grammar, a broader knowledge, emotion and even the precious time. Therefore, writing is not only making a line of sentence, which have no inter-connection between each other, but writing is making our written pieces worth and understood by the readers. 
Nowadays, government of Indonesia decides the Government Regulation No. 22/2006 about the national standard of education, written English is taught in schools in Indonesia focuses on text genre. The text genre or kind of text is studied by students in junior and senior high school. One of text genres that are studied is descriptive text. The descriptive text that is studied by the students of junior high school consists of a description and identification. According to the revised curriculum 2013 for the seventh grade, students are expected (1) to describe the social function of people, animals and thing either spoken or written, (2) to arrange or write a simple descriptive text with language elements and structure text correctly.

Even though, during preliminary study the researchers found the problems. The students' problems are (1) the students could not understand how to write descriptive text in suitable tenses, generic structure and language features correctly and (2) the students get the difficulties in expressing their idea in writing descriptive text. It is also supported by the data writing score from the teacher. Here the researchers would like to show the data writing score in table 1.1

Table 1.1 The data writing score at seventh grade at SMP N 2 Metro

\begin{tabular}{|c|c|c|c|}
\hline No. & The Scores & Classification & Students \\
\hline 1. & $80-100$ & Excellent & 3 \\
\hline 2. & $75-79$ & Good & 5 \\
\hline 3. & $65-75$ & Fair & 7 \\
\hline 4. & $55-64$ & Poor & 9 \\
\hline 5. & $10-50$ & Failed & 8 \\
\hline \multicolumn{2}{|c|}{ Total } \\
\hline
\end{tabular}

Source: The data of seventh grade students of SMP N 2 Metro academic year 2017/2018.

From the table 1.1, it can be seen that 3 students get excellent scores that is $80-100$ scores, 5 students get good scores that is $75-79$ scores, 7 students get fair scores that is $65-74$ scores, 9 students get poor scores that is 55-64 scores, and 8 students get failed scores that is 10-50 scores. It can be concluded that there are still many students got the low score.

The problems above are caused by (1) the students have low motivation in learning, it can be seen when the students feels not confident and lazy in learning process, (2) the students have low vocabulary in English, when the students write or speak English, most of them still confused for what they are going to speak because they do not have many words in English, (3) the students have low grammar, it can be seen when the students write a sentence they still make a mistake in a grammar.

Therefore, after considering the fact in the field, the researchers offers Guided Question Technique in teaching writing. Hidayah (2015) stated "a guided question is a technique for teaching in which the teacher gives some questions to the students applied to a topic in teaching". The advantage of used this technique is it can facilitate the teaching writing to the students, so that the students will not be confused what they are going to write. This technique is expected to give guidance about what should be included in students' writing.

\section{The Concept of Writing}

Writing is important in our life. Through writing, we can learn a lot of things, for the simplest one such as how to make a writing to describe thing or to be a tool to communicate. According to Masitoh and Suprijadi (2015: 39) stated that "writing is a thinking process of discovering ideas then written on the paper". Sokolik (in Maharaj, A. and Alsolami, T. 2018: 1) explains that writing is a mental process of generating ideas and deciding how best to present these ideas in the form of a written text. For many of foreign language learner, writing is considered as the most difficult skill because in writing they have to combine the 
correct grammar and also the coherence of the paragraph. Siburian (2013: 33) states that "writing is a whole brain activity to formulate and to organize ideas in right words to deliver and communicate the aims to the reader and present it on a piece of paper". Those are not the simple steps in writing because people have to realize that what they write is what they want to say or express.

According to Urrutia and Gutiérrez (2011: 14) said "Writing is important to share ideas and feelings, persuade and convince other people. It is a form of expression." It can be said that writing is a way to express the feelings and ideas to persuade the people.

Based on the theories above, the researchers can conclude that writing is the process of sharing ideas that written on a piece of paper to deliver and communicate a message to the readers.

\section{The Process of Writing}

Harmer (in Anggara, 2013: 9) states the writing process that is the stages the writer goes through in order to produce something in his final written form. Still, he states that there are four-steps in the writing process. They are planning, drafting, editing and final draft. Each step is described as follows:

1) Planning

In this stage, the students plan what they are going to write based on the ideas related to the topic. In planning, they have to consider three main issues, they are the purpose of writing, the audiences they are writing for and the content structure to sequence the fact, ideas or arguments which they have decided to include.

2) Drafting

After getting the plan, the students try to write their ideas related to the topic on the paper. They are going to write without paying attentions to the mistake.

3) Editing (reflecting and revising)

In this step, the students re-write their draft to see where is the important to write. It does to make the sentence is not ambiguous. The teacher may be taken in this step to help the students making a revision of their writing.

4) Final version

In the final version, the students make a change in their writing after editing process. The final writing may be different from the first draft after getting some steps in editing. It makes the students writing better.

\section{The Concept of Guided Question Technique}

Most of the students think that writing is the worrisome lesson. They have no idea for what they want to write about, so they cannot write anything. Because of that, the researchers use guided questions technique to overcome the problem. According to Wulandari, et al (2015: 3) state guiding questions is necessary for motivating the students to practice writing in accordance with their level of proficiency. It also supported by Giacomozzi (2007: 1) stated "Questioning techniques are a key element of the interactive classroom which is constantly being invented and revised to help facilitate active learning".

Guided question is a base question that applied for help the students to understand. Like Traver (in Ramadhani 2016: 98) states "a guiding question is the fundamental query that directs the search for understanding". In addition Hidayah (2015: 10) stated "a guided question is a technique for teaching in which the teacher gives some questions to the students applied to a topic in teaching".

Nawawi (2011: 27) said that guided questions is a method for teaching English in which the teacher gives some questions to the students applied to a topic in teaching writing. Moreover, guided questions can help developing writing topic, so it will be easier for the students to explore their idea to write. 
Based on the explanation above, the researchers concludes that guided questions technique is a technique of writing in order to facilitate active learning in guiding the students to explore their idea into a written form by giving some questions related to the topic.

\section{The Advantages of Guided Questions Technique}

There are several advantages of guided questions technique. Imanisa (2017: 17) states the advantages of guided questions technique are:

1) It can facilitate the teaching writing to the students, so that the students will not be confused what they are going to write because they are guided to write by the questions related to the topic.

2) It can make their writing more coherent because they write the paragraph by following the questions.

3) It can minimize mistakes by the students when they write.

\section{Teaching Writing Descriptive Text through Guided Questions Technique}

In teaching writing descriptive text through guided questions technique, the researchers used step from Reid (in Imanisa, 2017: 15-17). Those steps can be described as follow:

1) Pre-writing activity

a) The teacher explain about the descriptive text is, and also the generic structure of descriptive text,

b) The teacher decides the topic to be given to the students (the topic about $M y$ Friend),

c) The teacher gives some questions to students related to the topic.

2) Writing activity

a) Re-writing Activity The teacher ask the students to choose one of their friends,

b) The students begin to write the descriptive text by answering the questions that be given,

c) While the students are writing descriptive text, the teacher gives the guidance and assistance by moves among them.

3) This activity is intended to make the students evaluate and revise the mistakes in their writing.

a) The teacher monitors and marks the students' mistakes in their writing by giving a comment and suggestion.

\section{RESEARCH METHODOLOGY}

The research of this study classified as classroom action research. Basrowi and Suwandi (2008: 28) states that Classroom Action Research is action research in education sector what do in class area and have the goal to repair and or to increase the learning quality. Furthermore, Arikunto (2008: 104) stated action research is one of the type investigation that has characteristic reflective participative, collaborative, and spiral that have purpose to repair and to increase the system, method, process, substance, competence and situation.

In addition Kemmis and McTaggart (Arikunto, 2004: 132) said the action research is conducted through the process below:

From the explanation above, it can be concluded that classroom action research is a kind of research that has quality in doing learning process so it can repair and or increase the learning practices in classroom with more professional, then the researchers identified that the action research will be conducted through four activities; in which each activity consisted of four steps; they are planning, acting, observing and reflecting.

\section{Research Procedure}


The researchers use some steps that proposed by Arikunto (2007: 16). The procedures are as follows:

a. Planning

After identifying the problem, the researchers make a plan about what kind of action that will be carried out. Then, we prepare everything dealing with the action research requirements such as preparing the material, making lesson plan, preparing observation sheets to record students' activities, and preparing teaching aids and instrument.

b. Acting

In this step, the researcherss will aplly a lesson plan that have been made with the English teacher as the collaborator.

c. Observing

In this stage, the researcherss and the teacher of SMP N 2 Metro observe and monitor the activities in the classroom during and after teaching learning process by making notes of students' progress on writing skill.

d. Reflecting

After carrying out teaching and learning activity using guided questions technique, the researchers recite the occurrences in the classroom as the effect of the action. The researcherss and English teacher evaluate the process and the result of the implementation of guided questions technique in teaching writing. The evaluation gives advantages in deciding what the researchers and the English teacher have to do in next cycle.

e. Revising the plan

The revision is carried out according to the weaknesses found in the previous cycle. By revising the plan, it is hoped that the rest of the problems can be handled in the following cycle.

\section{Research Instrument}

In getting the data, the researcherss employ two kind of instruments. The instrument of this research are as follow:

a. Observation

The researchers checked some aspect in teaching and learning process by observation sheet. Observation sheet give the information about what is happening during learning process if the teacher applies guided question technique, especially in teaching descriptive text.

b. Interview

Interview is one of the techniques to collect data. The researchers use interview for obtaining data about the implementation of guided questions technique on students' writing skill.

c. Test

The test consists of pre-test and post test. The test is used to measure students' score on writing skill.

\section{Data Collecting Technique}

The data collected are qualitative in nature. However, there are quantitative data from students' pre-test and post-test mean scores. Furthermore, in collecting the data, the researchers used observation, interview and test.

\section{Data Analysis Technique}

According to Sugiono (2012: 92-99) the steps of data analysis divided into three phases, consisting of Data Reduction, Data Display and Conclusion Drawing are: 


\section{A. Qualitative Data Analysis}

a. Data Reduction

"Mereduksi data berarti merangkum, memilih hal-hal yang pokok, memfokuskan pada hal-hal yang penting, dicari tema dan polanya. Dengan demikian data yang telah di reduksi akan memberikan gambaran yang lebih jelas, dan mempermudah peneliti untuk melakukan pengumpulan data selanjutnya, dan mencarinya bila diperlukan".

Therefore, in analyzing the data contain selection process, focusing, and summarizing data from observation and interview. In this step, the researchers selected to minimize the amount of data that needed. Data reduction increase storage efficiency and reduce costs.

b. Data Display

The second step analyzing the data is describing the data in narrative. This step is describing the result of the research which is understandable. The form of displaying is not always in sentences, but can be in the form at table which supports the narrative data.

c. Conclusion Drawing

The last step is the researchers draw conclusion and gives suggestion of the research based on data analysis.

\section{B. Quantitative Data Analysis}

Beside qualitative data the researchers use quantitative data. The quantitative data will be used to analyze the result of two aspects below:

a. Test

The researchers make a test to measure the students' writing skill and to know whether the test success or not. The researchers ask students to make a descriptive paragraph by using guided question technique. To analyze the result, the researchers uses the formula of the percentage of success from Arikunto $(2010 ; 63)$ as fellow:

$$
\frac{\text { Total all passed students }}{\text { Number Of Students }} \text { X } 100
$$

The result of data analysis is compare with the criteria of success. If one of the indicators in the criteria of success has not been achieved yet, the next cycle is applied by making revision on the next planning. But, if the result of the data analysis show that all indicators in criteria of success have been achieved, the research stops and gets the final conclusion.

\section{Discussion}

According to the discussion of finding teaching and learning through guided questions technique, the result indicated that there are some improvement on the students' ability in writing descriptive text through the technique from $69,23 \%$ in first cycle gained score 70 or more become $93,75 \%$ achieved the score 70 to 84 in the second cycle. It is found that the implementation of guided questions technique is able to encourage the students to focus on writing skill of descriptive text, the students are enthusiasm and fast to keep their attention on writing ability.

The improvement happened because the effect of guided questions, the students is easier to explore their ideas, it made the students more interested in writing descriptive text. On the other hand, the students understood about the material which delivered to them. It meant that the instructions process ran well, as great as the result got.

Besides, it also influenced by the students' participation in every meeting in the cycle is improved. There is a rising score in each cycle and significant percentage progress of the students' participation in cycle 1 and cycle 2 . It also supported by the teacher interviews' 
result, the teacher said during the writing lesson used guided questions, the students performance is increased higher and higher in each activity in every cycle. The students' enthusiasm in learning writing used guided questions influenced their scores which became measurement of success in this research.

\section{Conclusionn}

The implementations of guided question technique in teaching writing at SMP N 2 Metro give some benefits:

1. First, the improvement of students' average score from pre-test to post-test 1 is $13,23 \%$. It based on the students' average score in pre-test is 56 or $6,25 \%$ who gained score 70 to 71 or two students pass the KKM to 69,23 or $59,375 \%$ (19 students) pass the KKM who got score $70-78$ in post test 1 .

2. Second, the improvement of post-test 1 to post-test 2 is $6,77 \%$, which is the students' average score of post test 1 is 69,23 or $59,375 \%$ (19 students) to 76 or (30 students) $93,75 \%$ which pass the KKM in post-test 2 .

3. Third, the result of students' motivation indicates the score progress in students' focused is $75 \%$ to $84,38 \%$, answering question is $56,25 \%$ to $78,13 \%$, giving opinion gained $59,38 \%$ to $71,88 \%$, asking to teacher is $59,38 \%$ to $75 \%$ and $100 \%$ for students who do the task in cycle 1 . In the post-test 2 the students' focused gained score $93,75 \%$ to $100 \%$, answering question is $90,63 \%$ to $93,75 \%$, giving opinion gained $84,38 \%$ to $87,5 \%$, asking to teacher is $90,63 \%$ to $93,75 \%$ and students who do the task is $100 \%$.

4. The last fact is based on the teacher's interview result can be concluded the teacher conveyed their opinion that guided questions is very effective to apply in writing descriptive text.

\section{REFERENCES}

Anggara, D, Y. 2013. The Effectiveness of Guided Writing in Improving the Students' Writing Ability of the Eighth Grade Students at Smp Negeri 2 Temon in the Academic Year of 2012/2013. S1 Skripsi: Unpublished. Yogyakarta: State University of Yogyakarta.

Arikunto, S. 2004. Prosedur Penelitian: Suatu Pendekatan Praktek. Bandung: Rineka Cipta p. 132

16. 2007. Dasar-dasar Evaluasi Pendidikan. Jakarta: PT. Bumi Aksara, p. 2008. Penelitian Tindakan Kelas. Jakarta: PT Bumi Aksara, p. 104.

Basrowi and Suwandi. 2008. Prosedure PTK: Referensi utama PTK untuk Guru serta Mahasiswa Keguruan dan Ilmu Pendidikan. Bogor: Ghalia Indonesia, p.28.

Ghanbari, B. (et. a.l). 2012. Rating Scales Revisited: EFL Writing Assesment Context of Iran under Scrutiny, Language Testing in Asia. Vol. 2, p. 94.

Giacomozzi, C. 2007. Questioning Techniques. Master Teacher Program: Unpublished. New York. 
Hidayah, I. 2015. The Effectiveness of Guided Questions toward Students' Writing Skill of Descriptive Text (An Quasi-Experimental Study at the Eight Grade Students of SMP N 3 Tangerang Selatan). S1 Skripsi: Unpublished. Jakarta: Syarif Hidayatullah State Islamic University.

Imanisa, S, T. 2017. Improving Students' Ability In Writing Descriptive Text through Guided Questions Technique at the Second Grade of SMP Negeri 23 Bandar Lampung. S1 Skripsi: Unpublished. Bandar Lampung: University of Lampung.

Maharaj, A. and Alsolami, T. 2018. The Questions Technique in Guided Paragraph Writing, International Journal of Emerging Trends in Social Sciences. Vol. 2, p. 1.

Masitoh, S. and Suprijadi, D. 2015. Improving Students' Ability in Writing Descriptive Text using Genre Based Approach (Gba) at the Eighth Grade Students of SMP Islam Terpadu Fitrah Insani, ELTIN Journal. Vol 3/1, p. 38.

Mutiara, R. 2014. Teaching Descriptive Text Writing through Guided Wh-Questions: A Pre-Experimental Study at the Eight Grade Students of Smp Negeri 7 Pontianak in Academic Year 2013/2014, WKS: Studies on English Language and Education. Vol. 1, p. 51.

Namasivayam, P. (et. al.). 2017. Improving ESL Students' Descriptive Writing through WH-Question Technique, ResearchGate. Vol. 7, p. 219.

Nawawi, M, B. 2011. Improving Students' Writing Skill of Descriptive Text through Guided Questions (A Classroom Action Research at VIII-8 class of SMP PGRI 1 Ciputat-Kota Tangerang Selatan). S1 Skripsi: Unpublished. Jakarta: Syarif Hidayatullah State Islamic University.

Ningsih, S. 2016. Guided Writing to Improve the Students' Writing Ability of Junior High School Students, EFL Journal. Vol. 1, p. 129.

Pardiyono. 2007. Pasti Bisa. Teaching Genre-Based Writing. Yogyakarta: CV. Andi Offset.

Ramadhani, A, A. 2016. Enriching the English Students' Speaking Ability using Recount Story Telling with Guided Questions at Stkip Muhammadiyah, Jurnal Perspektif. Vol. 01, p. 98.

Siahaan, S. 2011. English Generic Text Writing II Module. Unpublished: FKIP Universitas HKBP Nommensen.

Siburian, Asih, T. 2013. Improving Students' Achievement on Writing Descriptive Text through Think Pair Share, International Journal of Language Learning and Applied Linguistics World (IJLLALW). Vol. 3 (3), p. 30.

Sugiono. 2012. Memahami Pemahaman Kualitatif. Bandung; CV ALFABETA, p. 92-99.

Urrutia, L, J. and Gutiérrez, A, S, M. 2011. Adolescents' Awareness of Environmental Care: Experiences when Writing Short Descriptive Texts in English*, Profile Issues in Teachers' Professional Development. Vol. 13, p. 11. 
Wulandari. (et. al.). 2015. Improving Students' Ability in Writing Descriptive Paragraph through Guiding Question Technique. Pringsewu: Unpublished.

Zouaoui, M. 2010. Teaching Writing Strategies. Université Djillali Liabès Sidi-BelAbbès.

http://skripsi-fkip-inggris.blogspot.co.id/2013/04/conceptual-vs-theoriticalframeworks.html? $\mathrm{m}=1$ (Accessed on $6^{\text {th }}$ February 2018, at: 11:16 pm) 